\title{
PENGEKANGAN PENGGUNAAN SENJATA API SEBAGAI AKSES BAGI BEBAN KERJA UNTUK MEMPENGARUHI BERFIKIR IDE BUNUH DIRI MENGGUNAKAN SENJARA API
}

\author{
Tugimin Supriyari ${ }^{1}$, Erik Saut H Hutahaean ${ }^{2}$, Sandra Adetya ${ }^{3}$, Anifah $^{4}$, \\ Reny Kurniawan ${ }^{5}$ \\ Universitas Bhayangkara Jakarta Raya
}

\begin{abstract}
Abstrak
Kepolisian sudah mempunyai regulasi yang mengatur penggunaan senjata api pada personilnya. Penggunaannya menjadi sebuah tema yang diperhatikan serius, karena sangat berkaitan dengan tindak kekerasan. Terlebih lagi kekerasan terhadap diri sendiri yang tercermin melalui kejadian bunuh diri anggota polisi. Penelitian bermaksud menggali faktor langsung dan tidak langsung, untuk mendapatkan penjelasannya. Sebanyak 219 anggota kepolisian dilibatkan menjadi responden dan mengisi skala pengukuran; beban kerja, pengekangan senjata api, dan berfikir ide bunuh diri. Berdasarkan analisis data didapatkan bahwa beban kerja dapat berperan sebagai faktor langsung yang membentuk munculnya pikiran bunuh diri. Penelitian ini terbatas dalam lingkup sudut pandang personil dalam menilai keadaan-keadaan yang ada pada dirinya, kedepannya diperlukan perluasan linkupnya hingga sudut pandang organisasi. Seperti misalnya cara pemimpin mengelola beban kerja personilnya, tindakan organisasi dalam menangani masalah beban kerja personilnya dan melindungi personilnya dari resiko penyimpangan penggunaan senjata api.
\end{abstract}

Kata kunci : Pikiran untuk bunuh diri, anggota polisi, dan pengekangan senjata api

\begin{abstract}
The police already have regulations regarding the use of firearms in their personnel. Its use is a theme that is taken seriously, because it is related to acts of violence. Moreover, it was noticed because there were incidents of police officers who committed suicide. To get an empirical explanation, this research intends to explore direct and indirect factors. Police members were involved as many as 219 respondents and they filled the measurement scale; workload, restraint of firearms, and thinking of suicidal ideas. The results of data analysis get workload can act as a direct factor that shapes the emergence of suicidal thoughts. The limitations of this study are in terms of the scope of the personnel's point of view in assessing the conditions that exist in him. In the future it is necessary to expand its scope to the point of view of the organization. Such as the way leaders manage the workload of their personnel, the organization's actions in handling workload problems and protecting its personnel from the risk of irregularities in the use of firearms.
\end{abstract}

Keywords: Suicidal thoughts, police officers, and firearms restraints

1 email: *tugiminsupriyadi@gmail.com

Fakultas Psikologi Universitas Bhayangkara Jakarta Raya

Kebayoran Baru, Kota Jakarta Selatan, DKI Jakarta

Pengekangan Penggunaan Senjata Api Sebagai Akses Bagi Beban Kerja untuk Mempengaruhi

Berfikir Ide Bunuh Diri Menggunakan Senjara Api

Tugimin Supriyari, Erik Saut H Hutahaean, Sandra Adetya, Anifah, Reny Kurniawan 


\section{Pendahuluan}

Senjata api yang digunakan anggota polisi merupakan suatu alat kekerasan yang digunakan sebagai instrumen penegakan hukum atau bahkan penggunaan yang menyimpang. Personil mendapatkan ijin membawa dapat menggunakan senjatanya saat bertugas untuk kepentingan penegakan hukum (Hutahaean, 2015), seperti tindakan balasan terhadap penjahat yang memberikan perlawanan yang mengancam keselamatan jiwa, atau melumpuhkan gerak penjahat karena berusaha lari dalam proses penangkapan. Sisi lainnya juga memperlihatkan bahwa polisi menggunakan senjatanya secara tidak benar, salah satu yang paling menjadi perhatian adalah senjata digunakan untuk bunuh diri. Kepemilikan senjata api sangat berkaitan dengan kejadian bunuh diri (Miller, Warren, Hemenway, \& Azrael, 2015). Setidaknya dari tahun 2014 sampai dengan 2017 terlihat kemunculan kasus polisi bunuh diri dengan menggunakan senjata api, kasus tersebut menjadi bukti adanya penyalahgunaan senjata api, dan kemungkinan lemahnya pengekangan penggunaan senjata api dari personil yang melakukannya.

Hasil penelitian yang pernah dilakukan di Amerika memperlihatkan bahwa adanya penurunan tingkat bunuh diri yang diakibatkan adanya penerapan sistem pengekangan senjata api (Andreas \& Hempstead, 2011). Kendali secara pribadi penggunaan senjata api yang lemah menjadi faktor yang membuat polisi memilih untuk menghilangkan nyawanya sendiri. Pengekangan yang lemah menjadi faktor yang paling berperan dalam memunculkan pikiran bunuh diri menggunakan senjata api. Bunuh diri bukanlah perilaku spontan, tidak terjadi secara tiba-tiba, dan faktor kognitif yang tidak fleksibel dapat menjadi pemicunya (Miranda, Gallagher, Bauchner, Vaysman, \& Marroqu1, 2012). Pikiran membuat keputusan yang unik tentang benda yang mudah diakses oleh pelaku untuk bunuh diri, dan pikiran bekerja memikirkan situasi-siatuasi yang tepat untuk melaksanakannya (khususnya ketika tidak ada pilihan benda). Polisi yang membawa senjata api sangat besar kemungkinannya membuat keputusan memilih dan menggunakan senjata api dalam setiap permasalahan yang dihadapinya (Siegel \& Rothman, 2016).

Permasalahan tentang beban kerja yang sangat rumit dapat membuat upaya pikiran, dan proses perasaan menjadi semakin bertambah berat cara kerjanya. Interaksi yang tidak harmonis, kondisi keuangan yang sulit, kesehatan yang semakin memburuk membuat pikiran dan perasaan menjadi kacau. Keadaan seperti ini telah menjadi alasan untuk bunuh diri, terlebih lagi ketika sudah pada pikiran tidak ada jalan keluar untuk permasalahan yang dihadapinya. Hasil penelitian yang dilakukan pada subjek yang melakukan percobaan bunuh diri mendapatkan tentang pilihan bunuh diri adalah jalan keluar dari permasalahan. Orang-orang yang menganggap masalah tuntutan pekerjaannya sudah sangat 
berat, pikirannya menyimpulkan sudah tidak ada kekuatan untuk menyelesaikan tuntutan pekerjaannya, menilai bunuh diri sebagai jalan keluarnya.

Meskipun sulit untuk ditentukan karakteristik profil yang komit untuk bunuh diri, tetapi data kasus bunuh diri ada yang mengarah kepada fungsi kerja detektif (Aamodt \& Stalnaker, 1999). Pada satuan kerja tertentu maksimalnya proses kerja dapat dilihat melalui durasi kerja, dan resiko kerja yang akan dihadapinya, juga ditambah dengan tanggung jawab penyelasaian pekerjaan yang sulit diukur batas waktu penyelesaiannya. Misalnya dalam hal membongkar dan menangkap pelaku kejahatan. Jam kerja yang sangat panjang, ada banyak waktu harus diselesaikan lebih dari jam kerja pekerja reguler lainnya yang hanya 8 jam kerja. Resiko kematian, cacat, sakit fisik dan mental harus dihadapi oleh petugas polisi pada unit reserse dan kriminal umum, merupakan gambaran kualitas akan beban yang wajib dilaksanakan. Jumlah kasus kejahatan, atau kuantitas kendaraan yang sudah tidak wajar, juga menjadi objek yang akan menambah bertambah beratnya beban kerja pada satuan kerja tertentu. Hasil sebuah kajian studi menerangkan bahwa beban kerja yang ditunjukan melalui jama kerja yang sangat panjang dan kondisi pekerjaan yang buruk dapat menjadi faktor yang meningkatkan resiko bunuh diri (Sekhri, 2015).

Beberapa teori, kasus dan hasil penelitian sudah memperlihatkan pengaruh dari variabel yang berbeda (dalam cakupan varibel penelitian ini). Penulis belum menemukan hasil penelitian tentang berfikir ide bunuh diri dengan melibatkan anteseden beban kerja, dan kepatuhan personil untuk mengekang dirinya dalam menggunakan senjata api. Penelitian empiris tentang berfikir ide bunuh diri dengan subjek polisi sudah banyak dilakukan di luar Indonesia. Hasil penelitian ada yang telah mendapatkan fakta bahwa hasrat yang berlebihan menjadi faktor utama bagi kemunculan ide bunuh diri, dan ketika disertai dengan intrusive thoughts ide bunuh diri menjadi bertambah tinggi (Steyn, R., Vawda, N., Wyatt, G.E., Williams, J.K., Madu, 2013). Penelitian lainnya memperlihatkan hasil bahwa skor yang rendah pada kesadaran, stabilitas emosi, pendekatan coping, dan menjalankan religi sebagai menghindari coping dengan skor yang tinggi berhubungan dengan banyak ide bunuh diri (Meyer, R., Rothman, S., Pienaar, 2003). Eksposure yang mengakibatkan traumatis dapat meningkatkan resiko tingginya tingkat gejala PTSD, yang kemudian dapat meningkatkan resiko konsumsi alkohol yang tinggi dan ide bunuh diri (Violanti, 2004).

Cakupan penelitian ini meliputi empat pertanyaan penelitian. (1). Apakah pikiran untuk bunuh diri dapat dibentuk oleh beban kerja secara langsung?, (2). Apakah beban kerja dapat mengakibatkan terjadinya pengekangan senjata yang lemah?, (3). Apakah rendahnya pengekangan membentuk adanya pikiran untuk bunuh diri menggunakan senjata api?, (4) atau justru pikiran tentang ide bunuh

Pengekangan Penggunaan Senjata Api Sebagai Akses Bagi Beban Kerja untuk Mempengaruhi

Berfikir Ide Bunuh Diri Menggunakan Senjara Api

Tugimin Supriyari, Erik Saut H Hutahaean, Sandra Adetya, Anifah, Reny Kurniawan 
merupakan konsekuensi dari pengaruh tidak langsung yang beruntun dari beban kerja dan melewati pengekangan senjata api? Penelitian ini berusaha mendapatkan kerangka ilmiah yang objektif untuk dapat menjelaskan peristiwa polisi bunuh diri melalui kemunculan berfikir ide bunuh pada anggota polisi. Konstruk pemikirannya didasarkan kepada hasil penelitian sebelumnya, teori-teori, dan kasus-kasus yang terjadi pada anggota kepolisian. Hasil penelitian ini dapat dimanfaatkan kegiatan sebagai pengetahuan preventif dalam kegiatan psikoedukasi tentang kejadian bunuh diri, dan penyalahgunaan senjata api dilingkungan kerja kepolisian.

\section{Metode Penelitian}

Pelaksanaan penelitian dilakukan di wilayah kerja DKI Jakarta, dengan melibatkan sebanyak 48 responden untuk uji coba kelayakan instrumen penelitian. Uji coba dilakukan untuk mendapatkan fakta empiris mengenai keakuratan dan konsistensi butir untuk mengukur indikatornya. Pembuktian pertanyaan penelitian dilakukan dengan melibatkan sebanyak 219 subjek. Sampel dipilih berdasarkan karakteristik; membawa senjata api pistol dalam bertugas, kesehariannya bukan pada posisi desk (tetapi petugas lapangan), dengan tingkatan brigadir dan perwira pertama, memiliki jam kerja yang sangat panjang. Intrumen disebarkan dengan mekanisme disebarkan secara menggelinding, berdasarkan kesesuaian karakteristik dan kesediaan calon responden.

Data penelitian didapatkan melalui instrumen berupa skala pengukuran; skala beban kerja, skala pengekangan senjata, dan skala berfikir ide bunuh diri. Data penelitian yang diperoleh dari instrumen penelitian berupa data kontinum, yang berasal dari interval pilihan terhadap butir pernyataan. Data penelitian dianalisis menggunakan uji multi variat regression linier. Data diolah secara sistematik dengan cara menempatkan beban kerja sebagai variabel bebas, berfikir ide bunuh diri sebagai varibel terikat, dan pengekangan senjata api sebagai mediatornya. Analisa data dilakukan untuk mendapatkan gambaran mengenai pola beban kerja mempengaruhi berfikir ide bunuh, dengan melewati pengekangan penggunaan senjata api. Sehingga berbentuk seperti gambar di bawah ini : 


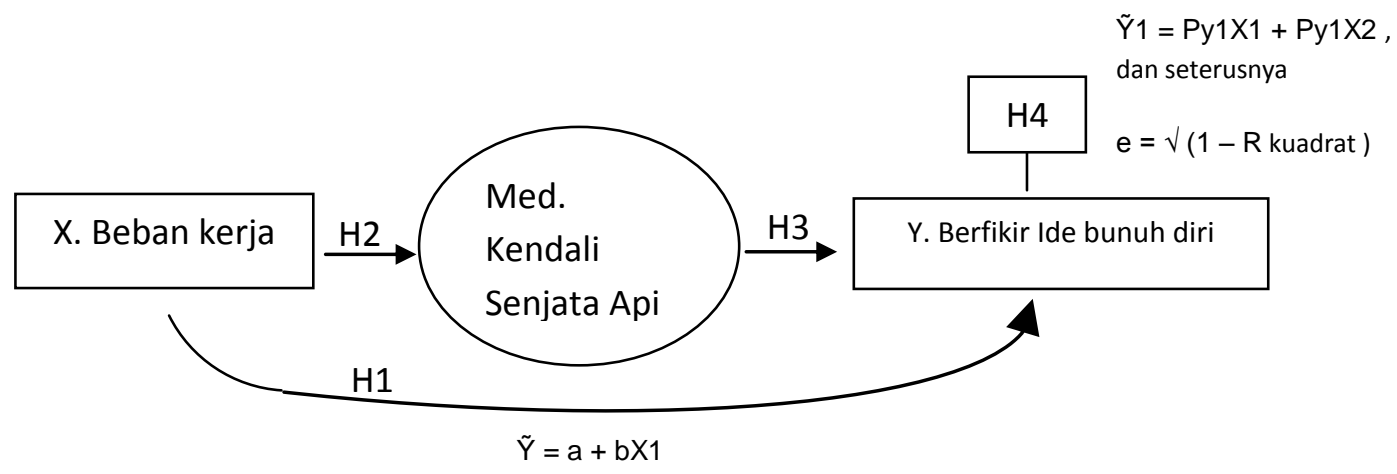

\section{Gambar.1. Desain Jalur Penelitian}

Analisis data juga dilakukan untuk mengidentifikasi kategori ukuran untuk setiap rata-rata skor subjek pada semua variabel penelitian, sehingga total skor yang diperoleh subjek dapat diketahui kategori tingkatannya. Analisis ini dilakukan untuk melengkapi penjelasan mengenai keadaan subjek berdasarkan pengukuran, dan mendeskripsikan pola peningkatan pengaruh yang diberikan beban kerja terhadap berfikir ide bunuh diri.

\section{Hasil dan Pembahasan}

Instrumen penelitian yang digunakan untuk mendapatkan data penelitian berupa alat ukur variabel, yang disusun dengan data metrik angka. Sebanyak tiga alat ukur yaitu; skala berfikir ide bunuh diri, skala pengekangan senjata api, dan skala beban kerja. Hasil uji coba dengan pendekatan satu kali penyajian alat ukur mendapatkan informasi bahwa ketiga skala penelitian dapat dijadikan sebagai instrumen pengumpul data penelitian. Beberapa teori tentang keterhandalan instrumen mensyaratkan tingkat validitas dan konsistensi skala dalam melakukan pengukuran. Syarat yang terstandar dapat menggambarkan tingkat kepercayaan butir dalam mengukur atribut.

Tabel 1. Hasil Uji Coba Alat Ukur

\begin{tabular}{lccccc}
\hline \multicolumn{1}{c}{ Variabel } & $\begin{array}{c}\text { Koefisien } \\
\text { Validitas }\end{array}$ & $\begin{array}{c}\text { Koefisien } \\
\text { Reliabilitas }\end{array}$ & $\begin{array}{c}\text { Jumlah } \\
\text { Butir }\end{array}$ & $\begin{array}{c}\text { Jumlah } \\
\text { Butir } \\
\text { Gugur }\end{array}$ & $\begin{array}{c}\text { Jumlah } \\
\text { Butir } \\
\text { Layak }\end{array}$ \\
\hline $\begin{array}{l}\text { Ide Bunuh } \\
\text { Diri }\end{array}$ & $0.627-0.856$ & 0.951 & 12 & 0 & 12 \\
$\begin{array}{l}\text { Pengekangan } \\
\text { Senjata Api }\end{array}$ & $0.466-0.583$ & 0.684 & 9 & 4 & 5 \\
Beban Kerja & $0.411-0.641$ & 0.716 & 10 & 4 & 6 \\
\hline
\end{tabular}

Pengekangan Penggunaan Senjata Api Sebagai Akses Bagi Beban Kerja untuk Mempengaruhi Berfikir Ide Bunuh Diri Menggunakan Senjara Api Tugimin Supriyari, Erik Saut H Hutahaean, Sandra Adetya, Anifah, Reny Kurniawan 
Hasil uji coba pada Skala pengekangan senjata api dan Skala beban kerja mendapatkan 4 butir tidak dapat digunakan untuk dijadikan sebagai butir pengukuran. Skala Pengekangan Senjata Api mendapatkan fakta sebanyak 44 persen butir tidak tepat dalam melakukan pengukuran. Pada Skala Beban Kerja didapatkan sebanyak 40 persen butir tidak akurat dalam melakukan pengukuran. Ketiga skala juga memperlihatkan tingkat butir konsistensi yang memadai untuk dapat mengukur variabel penelitian. Hasil uji coba butir dijadikan sebagai dasar untuk menyusun alat pengumpul data, sehingga didapatkan data jumlah butir untuk masing-masing skala (lihat tabel.1). Selanjutnya instrumen disebar kepada sebanyak 218 personil yang bertugas di wilayah kerja Polda Metro Jaya.

Hasil pengolahan data memperlihatkan ada pengaruh langsung dari beban kerja terhadap munculnya berfikir ide bunuh diri. Beban kerja berperan sebagai variabel yang mendahului munculnya ide pikiran untuk bunuh diri. Sebagai anteseden beban kerja memiliki peran sebagai salah satu yang mempengaruhi kemunculan fikiran untuk bunuh diri. Beban kerja yang sangat berat dan berlebihan menjadi kondisi negatif bagi personil polisi, begitu juga dengan beban kerja yang sangat rendah memunculkan kondisi negatif bagi personil, berupa perasaan tidak berguna (Anisi, Majdian, \& Mirzamani, 2010). Batas yang normal beban kerja polisi ada pada tingkatan sedang, dan berat yang tidak berlebihan. Beban kerja yang berat dapat dijelaskan dengan adanya tingkat kejahatan yang tinggi terjadi di satuan wilayah kerja Polda Metro Jaya (PuskominfoBidHumasPoldaMetroJaya, 2009)

Hasil hitung regresi lainnya pada beban kerja, juga memperlihatkan adanya peran yang berpengaruh dalam membentuk berfikir ide bunuh diri. Beban kerja terlihat menjadi salah faktor yang memberikan dampak kepada pengekangan diri personil dalam hal menggunakan senjata apinya, akibatnya penggunaan senjata tidak lagi untuk menjaga keamanan publik (Irsan, 2015). Konsekuensi dari beban kerja yang sangat berat adalah munculnya kecenderungan lengah untuk mengekang diri gunakan senjata api, berpeluang terjadinya penyalahgunaan senjata api. Kuat ataupun lemahnya personil polisi untuk mengekang dirinya dapat ditentukan oleh beban kerja yang dirasakannya, terutama jika beban kerjanya sangat banyak muatan luapan emosi yang negatif.

Tabel 2. Hasil Analisis Data Pengaruh Langsung

\begin{tabular}{cccc}
\hline Uji Analisa & Hasil Analisis & Nilai F & Nilai Signifikansi \\
\hline H1 & Diterima & 0.9708 & 0.002 \\
H2 & Diterima & 21.499 & 0.000 \\
H3 & Ditolak & 0.823 & 0.365 \\
\hline
\end{tabular}


Hasil analisa pada data yang ketiga memperlihatkan bahwa pengekangan penggunaan senjata api tidak dapat berperan mempengaruhi munculnya pikiran ide bunuh diri. Pengekangan penggunaan senjata api tidak dapat menjadi faktor yang berpengaruh langsung, memerlukan peranan dari variabel lainnya agar dapat memberikan pengaruh. Terjadinya proses individu berfikir ide bunuh diri dengan gunakan senjata api yang disebabkan langsung oleh pengekangan tidak ditemukan faktanya. Tetapi ketika beban kerja akan mempengaruhi fikiran untuk bunuh diri dengan melewati pengekangan senjata, beban kerja berhasil memberikan pengaruhnya terhadap variabel berfikir ide bunuh diri. Nampaknya pengekangan menjadi jalur terjadinya akses pelanggaran administrasi ketika beban kerja masuk mempengaruhi munculnya fikiran bunuh diri menggunakan senjata api (Tien \& Rich, 2005).

Hasil hitung statistik mengenai pengaruh tidak langsung beban kerja terhadap berfikir ide bunuh diri melalui pengekangan senjata api memperlihatkan tidak ada pengaruh yang signifikan. Nilai hasil hitung memperlihatkan 0.166, jika dibandingkan dengan nilai pengaruh langsung beban kerja terhadap berfikir ide bunuh diri (0.207) ternyata nilainya lebih kecil, hal ini mengindikasikan tidak terjadi pengaruh tidak langsung (lihat Tabel. 3). Sesuai lingkup tulisan ini , ternyata pengekangan penggunaan senjata api tidak dapat menjadi pengahantar bagi beban kerja dalam memberikan sumbangan terhadap terbentuknya berfikir ide bunuh diri. Hasil ini beroposisi dengan penelitian sebelumnya yang mengemukakan pengendalian penggunaan senjata api dapat menurunkan tingkat bunuh diri. Seperti pengendalian yang berupa izin dan persyaratan perizinan memiliki dampak negatif terhadap tingkat bunuh diri pada pria (Andreas \& Hempstead, 2011). Berarti pengekangan senjata api yang ketat oleh subjek (tinggi sesuai kategori tabel 4) tidak dapat digunakan untuk menjelaskan hubungan ataupun pengaruh secara langsung terhadap terbentuknya berfikir ide bunuh diri. Hal ini membuka kemungkinan bahwa berfikir ide bunuh diri dapat terjadi karena faktor anteseden lainnya, ataupun pengekangan pada kategori yang lemah, dan bukan karena pengekangan senjata api yang ketat.

Pengekangan Penggunaan Senjata Api Sebagai Akses Bagi Beban Kerja untuk Mempengaruhi

Berfikir Ide Bunuh Diri Menggunakan Senjara Api

Tugimin Supriyari, Erik Saut H Hutahaean, Sandra Adetya, Anifah, Reny Kurniawan 
Tabel.3. Analisis Pengaruh Tidak Langsung (H4)

\begin{tabular}{lc}
\hline \multicolumn{1}{c}{ Analisis Beta } & Nilai Beta \\
\hline Beban kerja terhadap berfikir ide bunuh diri (XZ) & 0.207 \\
Beban kerja terhadap pengekangan penggunaan & 0.301 \\
senjata api (XY) & \\
Pengekangan penggunaan senjata api terhadap & -0.136 \\
berfikir ide bunuh diri (YZ) & \\
$(\mathrm{XY}) \times(\mathrm{YZ})$ & 0.04093 \\
$(\mathrm{XZ})$ ditambah hasil kali $((\mathrm{XY}) \mathrm{x}(\mathrm{YZ}))$ & 0.16664 \\
\hline
\end{tabular}

Analisis kategori nilai rerata juga turut dianalisis dalam penelitian, hasil analisis mendapatkan ukuran tingkatan kandungan variabel penelitian. Analisis dihitung dengan lima tingkatan kategori; sangat rendah, rendah, sedang, tinggi, dan sangat tinggi. Hasil hitung mendapatkan rentangan skor untuk setiap kategori (lihat Tabel.4). Merujuk kepada angka mean empirik dapat diketahui bahwa; tingkatan berfikir ide bunuh diri pada subjek adalah rendah, tingkatan beban kerja dan pengekangan penggunaan senjata api tergolong tinggi. Jika merujuk kepada hasil hitung pengaruh tidak langsung, tingginya kepatuhan untuk mengekang diri dalam penggunaan senjata api tidak bisa menjadi anteseden yang mendahului fikiran untuk bunuh diri menggunakan senjata api (lihat nilai signifikansi H3 pada Tabel.2).

Berbeda halnya dengan beban kerja, dalam kadar yang tinggi dapat dipakai untuk menjelaskan muncul fikiran tentang ide bunuh diri gunakan senjata api (lihat nilai signifikansi H3 pada Tabel.2 dan Tabel.4). Dalam kadar yang tinggi beban kerja terbukti memberikan sumbangan munculnya fikiran ide bunuh diri. Meskipun kadar berfikir ide bunuh diri dalam kategori rendah, beban kerja yang tinggi dapat menjadi faktor yang berpengaruh terhadapnya. Resiko naiknya beban kerja akan berdampak kepada naiknya tingkatan untuk berfikir ide bunuh diri dengan senjata api. Salah satu hal yang dapat menjelaskan beban kerja yang berat adalah jam kerja, dengan jam kerja yang terlalu panjang dapat memunculkan ide bunuh diri. Sebuah hasil penelitian yang dilakukan pada pekerja pria menunjukkan bahwa ide bunuh diri dapat dipengaruhi oleh jam kerja yang panjang dengan interval 51-60 jam perminggu (Yoon, Bae, Kang, \& Yoon, 2015). 
Tabel.4. Hasil Analisis Kategori

\begin{tabular}{lccc}
\hline Keterangan & $\begin{array}{c}\text { Berfikir Ide } \\
\text { Bunuh Diri }\end{array}$ & $\begin{array}{c}\text { Pengekangan } \\
\text { Senjata Api }\end{array}$ & $\begin{array}{c}\text { Beban } \\
\text { Kerja }\end{array}$ \\
\hline Aitem Valid & 12 & 5 & 6 \\
Skor Minimum Hipo & 12 & 5 & 6 \\
Skor Maksimum Hipo & 72 & 25 & 30 \\
Rentangan Hipo & 60 & 20 & 24 \\
Total Empirik & 5140 & 4370 & 4950 \\
Mean Empirik & 23.58 & 20.045 & 22.706 \\
Mean Hipotetik & 42 & 15 & 18 \\
SD Hipotettik & 10 & 3.33 & 4 \\
MH-2SD & 22 & 8.33 & 10 \\
MH-1SD & 32 & 11.66 & 14 \\
MH- & $>32-<52$ & $>11.67-<18.33$ & $>14-<22$ \\
1SD $\leq$ ME<MH+1SD & 52 & 18.33 & 22 \\
M+1SD & 86 & 31.66 & 38 \\
M+2SD & $\leq 10$ & $\leq 3.33$ & $\leq 10$ \\
Sangat Rendah & $>\mathbf{1 0}-\mathbf{3 2}$ & $>3.33-11.67$ & $>10-14$ \\
Rendah & $>32-<52$ & $>11.67-<18.33$ & $>14-<22$ \\
Sedang & $52-<83$ & $\mathbf{1 8 . 3 3 - < 3 1 . 6 7}$ & $\mathbf{2 2}-<\mathbf{3 8}$ \\
Tinggi & $\geq 83$ & $\geq 31.67$ & $\geq 38$ \\
Sangat Tinggi & & &
\end{tabular}

Dalam kondisi beban kerja yang kadarnya tinggi ternyata dapat mempengaruhi pengekangan senjata api yang lebih ketat (kategori tinggi lihat tabel 4). Hasil penelitian memperlihatkan beban kerja dapat mempengaruhi pengekangan senjata api secara positif, artinya dalam kondisi beban kerja yang tinggi maka subjek mengekang dirinya lebih kuat lagi dalam menggunakan senjata api miliknya.

\section{Kesimpulan}

Beban kerja terbukti dapat memberikan pengaruh langsung terhadap berfikir ide bunuh diri, dalam tingkatan yang tinggi beban kerja dapat memberikan pengaruh terhadap variabel berfikir ide bunuh diri dengan gunakan senjata api. Beban kerja juga terbukti dapat memberikan pengaruh terhadap pengekangan senjata api, dalam keadaan beban kerja yang tinggi pengekangan penggunaan senjata api dilaksanakan secara ketat. Kondisi tuntutan pekerjaan yang tinggi dapat menjadi faktor yang membentuk tingkat kepatuhan untuk

Pengekangan Penggunaan Senjata Api Sebagai Akses Bagi Beban Kerja untuk Mempengaruhi Berfikir Ide Bunuh Diri Menggunakan Senjara Api 
mengatur penggunaan senjata api sesuai dengan aturan yang berlaku, cenderung dapat meminimalkan resiko melakukan pelanggaran.

Pengekangan penggunaan senjata api tidak terbukti dapat memberikan pengaruh terhadap variabel berfikir ide bunuh diri. Ketaatan terhadap aturan penggunaan senjata api tidak memberikan sumbangan yang berarti terhadap munculnya fikiran tentang ide bunuh diri menggunakan senjata api. Ketika pengekangan menjadi akases bagi beban kerja, terbukti tidak dapat membantu beban kerja dalam mempengaruhi munculnya ide untuk bunuh diri dengan gunakan senjata api. Pengekangan senjata api yang tinggi nampaknya menjadi variabel yang tidak dapat dikaitkan dengan kemunculan fikiran untuk bunuh diri dengan senjata api. Fikiran untuk bunuh diri dapat terbentuk karena ada pengaruh beban kerja yang tinggi.

Kelanjutan dari hasil penelitian ini sebaiknya diarahkan kepada analisa yang lebih mendalam lagi tentang resiko atau konsekuensi yang lainnya dari beban kerja, dan relevan dengan fenomena penyimpangan penggunaan senjata api. Seperti misalnya dapat diarahkan kepada atribut-atribut psikis yang sumbernya berasal dari proses terbentuknya stres organisatoris (Chae, M.H., Boyle, 2013), contohnya adalah proses dan pola kepemimpinan yang dapat memberikan kenyamanan kerja. Khususnya terkait dengan cara pimpinan mengatur pendelegasian tugas, cara pepmimpin memberikan dukungan terhadap personilnya ketika berhadapan dengan tuntutan kerja yang berat, dan peranan dari kepimimpinan dalam melindungi personilnya dari resiko penyimpangan penggunaan senjata api.

\section{Daftar Pustaka}

Aamodt, M. G., \& Stalnaker, N. A. (1999). Police Officer Suicide $\square$ : Frequency and Officer Profiles. In FBI Conference on Suicide and Law Enforcement, Quantico, VA (pp. 1-12).

Andreas, A. R., \& Hempstead, K. (2011). Gun Control and Suicide: The Impact of State Firearm Regulation in the United State, 1995-2004. Health Policy, 101, $1-2$.

Anisi, J., Majdian, M., \& Mirzamani, S. M. (2010). The factors Associated with Suicide Ideation in Iranian Soldiers. Iranian Journal of Psychiatry, 5(3), 97101. Retrieved from http://www.pubmedcentral.nih.gov/articlerender.fcgi?artid=3430507\&tool=p mcentrez\&rendertype $=$ abstract

Chae, M.H., Boyle, D. J. (2013). Police Suicide $\square$ : prevelance , risk , and protective factors. Policing: An International Journal of Police Strategies \& 
Management,

$36(1)$,

$91-118$.

https://doi.org/https.//doi.org/10.1108/1363951131130249

Hutahaean, E. S. H. (2015). Psikologi Kepolisian $\square$ : Seragam , Pangkat dan Senjata Api. In Prosiding PESAT 6.

Irsan, K. (2015). Polisi, Kekerasan dan Senjata Api $\square$ : Tantangan Pemolisian di Era Demokrasi. Jurnal Keamanan Nasional, 1(2).

Meyer, R., Rothman, S., Pienaar, J. (2003). Coping, Stres and Suicide Ideation in the South African Poilce Service in the Eastern Cape. SAJEMS NS, 6(4), 81104.

Miller, M., Warren, M., Hemenway, D., \& Azrael, D. (2015). Firearms and suicide in US cities. Injury Prevention, 21(1), e116-e119. https://doi.org/http://dx.doi.org/10.1136/injuryprev-2013-040969

Miranda, R., Gallagher, Ã. M., Bauchner, B., Vaysman, R., \& Marroqu1, B. (2012). PREDICTOR OF SUICIDAL IDEATION AMONG YOUNG, 186(September 2011), 180-186. https://doi.org/10.1002/da.20915

PuskominfoBidHumasPoldaMetroJaya. (2009). Police Workload (Beban Kerja Polisi).

Sekhri, S. (2015). Suicide Ideation $\square$ : Role of Psychological and Social Factors among Indian Police Officers. The International Journal of Indian Psychology, 2(4).

Siegel, M., \& Rothman, E. F. (2016). Firearm Ownership and Suicide Rates Among US Men and Women , 1981-2013. American Journal of Public Health, 106(7), 1-11. https://doi.org/10.2105/AJPH.2016.303182

Steyn, R., Vawda, N., Wyatt, G.E., Williams, J.K., Madu, S. N. (2013). Postraumatic stress disorder diagnostic criteria and suicidal ideation in a South African Police sample. Afr J Psychiatry, 16, 19-22. https://doi.org/doi:http:/dx.doi.org/10.4314/ajpsy.v16i1.3

Tien, R. M., \& Rich, T. F. (2005). Pengendalian Senjata Api: Sistem Verifikasi. In Ilmu Kepolisian (Edisi Bahasa Indonesia) (pp. 409-414). YPKIK.

Violanti, J. . (2004). Predictors of Police Suicide Ideation. Suicide and LifeThreatning, The American of Suicodology.

Yoon, C. G., Bae, K. J., Kang, M. Y., \& Yoon, J. H. (2015). Is suicidal ideation

Pengekangan Penggunaan Senjata Api Sebagai Akses Bagi Beban Kerja untuk Mempengaruhi

Berfikir Ide Bunuh Diri Menggunakan Senjara Api

Tugimin Supriyari, Erik Saut H Hutahaean, Sandra Adetya, Anifah, Reny Kurniawan 
linked to working hours and shift work in Korea? Journal of Occupational Health, 57(3), 222-229. https://doi.org/10.1539/joh.14-0237-OA 